\title{
BMJ Open Exploiting science? A systematic analysis of complementary and alternative medicine clinic websites' marketing of stem cell therapies
}

\author{
Blake Murdoch, ${ }^{1}$ Amy Zarzeczny, ${ }^{2}$ Timothy Caulfield ${ }^{1}$
}

To cite: Murdoch $B$, Zarzeczny A, Caulfield T. Exploiting science? A systematic analysis of complementary and alternative medicine clinic websites' marketing of stem cell therapies. BMJ Open 2018;8:e019414. doi:10.1136/ bmjopen-2017-019414

- Prepublication history for this paper is available online. To view these files, please visit the journal online (http://dx.doi org/10.1136//bmjopen-2017019414).

Received 31 August 2017

Revised 2 January 2018

Accepted 9 January 2018

Check for updates

${ }^{1}$ Faculty of Law, Health Law Institute, University of Alberta, Edmonton, Canada

2Johnson Shoyama Graduate School of Public Policy, University of Regina, Regina, Canada

Correspondence to

Timothy Caulfield;

caulfield@ualberta.ca

\section{ABSTRACT}

Objective To identify the frequency and qualitative characteristics of stem cell-related marketing claims made on websites of clinics featuring common types of complementary and alternative medicine practitioners. The involvement of complementary and alternative medicine practitioners in the marketing of stem cell therapies and stem cell-related interventions is understudied. This research explores the extent to which they are involved and collaborate with medical professionals. This knowledge will help with identifying and evaluating potential policy responses to this growing market.

Design Systematic website analysis.

Setting Global. US and English-language bias due to methodology.

Main outcome measures Representations made on clinic websites in relation to practitioner types, stem cell therapies and their targets, stem cell-related interventions. Statements about stem cell therapies relating to evidence of inefficacy, limited evidence of efficacy, general procedural risks, risks specific to the mode of therapy, regulatory status, experimental or unproven nature of therapy. Use of hype language (eg, language that exaggerates potential benefits).

Results 243 websites offered stem cell therapies. Many websites advertised stem cell transplantation from multiple sources, such as adipose-derived (112), bone marrow-derived (100), blood-derived (28), umbilical cordderived (26) and others. Plant stem cell-based treatments and products (20) were also advertised. Purposes for and targets of treatment included pain, physical injury, a wide range of diseases and illnesses, cosmetic concerns, non-cosmetic ageing, sexual enhancement and others. Medical doctors (130), chiropractors (53) and naturopaths (44) commonly work in the clinics we found to be offering stem cell therapies. Few clinic websites advertising stem cell therapies included important additional information, including statements about evidence of inefficacy (present on only $12.76 \%$ of websites), statements about limited evidence of efficacy (18.93\%), statements of general risks $(24.69 \%)$, statements of risks specific to the mode(s) of therapy $(5.76 \%)$, statements as to the regulatory status of the therapies $(30.86 \%)$ and statements that the therapy is experimental or unproven (33.33\%). Hype language was noted $(31.69 \%)$.

Conclusions Stem cell therapies and related interventions are marketed for a wide breadth of conditions and

\section{Strengths and limitations of this study}

- The involvement of complementary and alternative medicine practitioners in the marketing of stem cell therapies and stem cell-related interventions is understudied, and this research helps us understand the extent to which they are involved, and also the extent to which they collaborate with medical professionals.

- The methodology was designed in such a way that human error was minimised; manual searching of websites was largely replaced by automated domain searches by Google, which helped coders to achieve near perfect agreement in Cohen's kappa reliability testing.

- The search terms selected did not fully encompass the gamut of existing complementary and alternative medicine practitioner types, omitting some less common types such as reiki providers and reflexologists.

- Because the coding frame was applied solely to the specific webpages on web domains where the term 'stem cell' was found by Google, and not to the entirety of existing content on a given domain, it is possible that broad disclaimers and other relevant information were excluded.

are being offered by complementary and alternative practitioners, often in conjunction with medical doctors. Consumer protection and truth-in-advertising regulation could play important roles in addressing misleading marketing practices in this area.

\section{INTRODUCTION}

Stem cell research has considerable clinical potential and scientific discoveries continue to advance our knowledge in this field. ${ }^{12}$ Yet, despite enthusiastic media coverage of the field, ${ }^{3}$ only a few stem cell-based therapies are currently ready for clinical application. ${ }^{4-6}$ This reality has not stopped the proliferation of clinics around the world advertising a wide array of unproven stem cell-based interventions. ${ }^{7-9}$ Many of these 


\section{Box 1 Coding frame summary}

- In what country is the physical address listed on the clinic website located?

-What practitioner types are listed as clinic staff on the web domain? Choose all that apply (see table 5 for coding categories).

- What types of stem cell therapies or products, as defined by the claimed source of the stem cells and their mode of usage, are marketed? Choose all that apply (see table 4 for coding categories).

- What categories of conditions are targeted by the therapies advertised? Choose all that apply (see table 3 for coding categories). Notes on coding categories:

- The 'other illness/disease' category is defined as diseases or maladies including autoimmune disorders, degenerative conditions, genetic disorders, infectious diseases and environmental harms, other than chronic conditions primarily affecting on the bones, joints and muscles.

- The 'ageing' category includes issues related to ageing that are not cosmetic or aesthetic. This clearly distinguishes it from the 'cosmetic' category.

- What other treatments mentioning stem cells but not actually using them are marketed? Choose all that apply (see table 2 for coding categories).

- Are there any statements relating to the stem cell therapy or therapies indicating there is evidence of inefficacy?

- Are there any statements relating to the stem cell therapy or therapies indicating there is limited evidence of efficacy?

- Are there any statements relating to the stem cell therapy or therapies indicating the general risks of the procedure? (eg, minor risk of infection from injection, minor risk of allergic response, side effects of pain or soreness)

- Are there any statements relating to the stem cell therapy or therapies indicating the risks specific to the mode of therapy? (eg, worsening joint pain or joint malfunction caused by the injection of stem cells, unintended growth of different tissue)

- Are there any statements relating to the stem cell therapy or therapies indicating regulatory status? (eg, U.S. Food and Drug Administration approved or not)

- Are there any statements relating to the stem cell therapy or therapies indicating that the therapy is experimental or unproven?

- Are there any statements relating to the stem cell therapy or therapies that use hype language? This is defined as exaggerated or extreme language when speaking about potential benefits, for example, breakthrough, revolution/revolutionary, cure, incredible, amazing and magical.

clinics use a direct-to-consumer marketing system based on an online presence. ${ }^{10}{ }^{11}$ While much of the early growth in the commercial market for unproven stem cell-based interventions occurred in Asia, ${ }^{12}$ it is currently spreading to jurisdictions throughout the world. ${ }^{913}$ Furthermore, complementary and alternative medicine (CAM) practitioners have begun to offer stem cell-based interventions, marking a further expansion of this market.

Many of these interventions are marketed despite lack of approval by relevant regulatory bodies like the US Food and Drug Administration's (FDA's) Center for Biologics Evaluation and Research. ${ }^{10}$ The market also continues to flourish despite denunciation by research bodies like the
International Society of Stem Cell Research, ${ }^{5}$ cautions issued by professional societies ${ }^{14}$ and legislative attempts to constrain it, ${ }^{15}$ among other efforts. The apparent resilience of this market suggests regulators and policymakers need to explore diverse approaches for addressing the various concerns associated with it. ${ }^{16}$

While there are services that seek to encourage websites to provide accurate health information, ${ }^{17}$ the continued proliferation of misleading marketing highlights the need for additional steps. ${ }^{16}$ Indeed, there may be a relationship between low-quality health information and the presence of marketing for products and services. ${ }^{1718} \mathrm{~A}$ key skill for individuals is the ability to distinguish between trustworthy sources of health information and unreliable purveyors of misinformation. Misinformation is a concern for various reasons, particularly where it may be relied on by people making health-related decisions. Consumer protection and truth-in-advertising laws have been proposed as potentially useful avenues of response to health misinformation, ${ }^{19}$ as has greater use of professional discipline to govern the conduct of providers who are members of regulated health professions, with a particular focus on physicians. ${ }^{20}$

In order to evaluate the potential utility of these and other related strategies, it is important to understand, first, what kinds of healthcare providers (beyond physicians) are purportedly providing these unproven interventions, and second, how these services are being marketed to the public (ie, are the claims being made potentially inaccurate or misleading?). Identifying the professional status of those involved in the marketing of unproven stem cellbased interventions is necessary for ascertaining whether or not they are subject to professional regulation, and if so, what relevant rules govern their conduct in this field. At the same time, gathering data on the specific nature of the claims being made will highlight where existing consumer protection and truth-in-advertising laws may be triggered.

The ways in which CAM practitioners (as well as interdisciplinary clinics featuring CAM practitioners) use stem cells to market their services and the nature of the claims they are making are understudied. Given the trend of CAM practitioners framing themselves as primary care providers, ${ }^{21} 22$ and their tendencies to offer unproven interventions, ${ }^{23}$ we hypothesised that such practitioners have begun to offer unproven stem cell therapies and that they might make potentially misleading marketing claims about them. This raises potential safety concerns, particularly if the practitioner is not adequately trained in the relevant procedure. In addition, marketing of this kind raises the issue of 'scienceploitation'. ${ }^{24}$ 'Scienceploitation' occurs when popular scientific ideas, such as stem cells, are used to take advantage of the social capital associated with them and induce consumer interest in products or services. It is a potentially harmful practice that can mislead the public and damage public trust in legitimate science. 'Scienceploitation' is related to but distinct from hype as 
Table 1 Modes of stem cell therapy offered (among web domains marketing stem cell therapies, $n=243$ )

\begin{tabular}{llll} 
Therapy type & $\begin{array}{l}\text { Web } \\
\text { domains (n) }\end{array}$ & $\begin{array}{l}\text { Web } \\
\text { domains (\%) }\end{array}$ & Example (excerpt) \\
\hline $\begin{array}{l}\text { Adipose-derived } \\
\text { autologous stem cell } \\
\text { transplantation therapy }\end{array}$ & 112 & 46.09 & $\begin{array}{l}\text { 'Adipose Derived Stem Cell (ADSC) Therapy: Adult stem cell injection } \\
\text { is a groundbreaking treatment for orthopedic injury and other common } \\
\text { causes of musculoskeletal pain, osteoarthritis, back or neck injury and } \\
\text { joint pain -and, in many cases, it may be the preferred alternative to } \\
\text { orthopedic surgery.' (http://www.centerforintegratedmed.com/) }\end{array}$ \\
$\begin{array}{l}\text { Bone marrow-derived } \\
\text { autologous stem cell } \\
\text { transplantation therapy }\end{array}$ & 100 & 41.15 & $\begin{array}{l}\text { 'My clinical practice mission is to use autologous concentrated } \\
\text { marrow-derived mononuclear cells for the care and treatment of a } \\
\text { joint afflicted by degenerative arthritis so as to assist a patient in } \\
\text { postponing, perhaps avoiding a joint replacement.' (http://www. } \\
\text { sheinkopmd.com/) }\end{array}$
\end{tabular}

$\begin{array}{lll}\begin{array}{l}\text { Plant stem cell therapies } 20 \\ \text { and products }\end{array} & 8.23 & \begin{array}{l}\text { 'Gemmotherapy-made from plant stem cells, they have the ability to } \\ \text { detoxify, nourish, and regenerate tissues in the body.' (http://www. } \\ \text { demarcohomeopathy.com/) }\end{array} \\ \begin{array}{l}\text { Circulating blood-derived } 28 \\ \text { autologous stem cell } \\ \text { transplantation therapy }\end{array} & \begin{array}{l}\text { 'We perform a large blood draw (usually about } 300 \mathrm{cc} \text { ) from which } \\ \text { we harvest stem cells. [...] Once the stem cells have multiplied, they } \\ \text { are washed and screened again. The implantation is very simple and } \\ \text { practically painless. The stem cells are simply injected under the skin } \\ \text { into the lymphatic system where they can spread out in the body.' } \\ \text { (http://www.infisio.org/) }\end{array}\end{array}$

\begin{tabular}{|c|c|c|c|}
\hline $\begin{array}{l}\text { Umbilical cord blood- } \\
\text { derived stem cell } \\
\text { transplantation therapy }\end{array}$ & 26 & 10.70 & $\begin{array}{l}\text { 'The body's immune system is unable to recognize umbilical cord- } \\
\text { derived mesenchmyal stem cells as foreign and therefore they are not } \\
\text { rejected. HUCT stem cells have been administered thousands of times } \\
\text { at the Puhua Hospital and there has never been a single instance } \\
\text { rejection (graft vs. host disease).' (http://www.puhuahospital.com/) }\end{array}$ \\
\hline Other & 35 & 14.40 & $\begin{array}{l}\text { 1. 'Frequently Asked Questions: Why does Dr. Gonzalez use human } \\
\text { term placenta stem cells (HTPSCS) as opposed to umbilical cord } \\
\text { blood, fat cells from the same sick person or cells from discarded } \\
\text { embryos or aborted fetuses?' (http://www.integramedicalcenter. } \\
\text { com/) } \\
\text { 2. 'Disclaimer: All American Healthcare New Orleans does not use } \\
\text { any stem cells that originate from an embryo. All of our stem cells } \\
\text { used in stem cell therapy and regenerative medicine originate } \\
\text { from the amniotic sac and amniotic fluid.' (http://www.neworleans. } \\
\text { allamericanhealthcare.net/) } \\
\text { 3. 'Patients may receive between } 1 \text { to } 12 \text { injections. The amount } \\
\text { of cells per injections varies between } 5 \text { Million to } 20 \text { Million of } \\
\text { Embryonic Stem Cells.' (http://www.a1stemcells.com/) }\end{array}$ \\
\hline
\end{tabular}

the former goes beyond mere exaggeration and creates misunderstandings and/or posits false connections.

Improving understanding about CAM involvement in the private stem cell market will support identification and evaluation of available policy options in this field and will also contribute to broader considerations of issues associated with the marketing of CAM products and services in general. Accordingly, the goal of this research was to identify CAM providers advertising stem cell-related interventions via publicly accessible websites, and then to map the types of claims being made about those interventions. We first sought to identify relevant clinic websites using search terms focused on CAM practitioner types (eg, 'naturopaths') and common CAM terminology (eg, 'holistic'), and then to analyse the information presented on those clinic websites about stem cells and stem cell-related therapies.

\section{METHODS}

In order to establish a data set of web domains owned by relevant clinics offering stem cell-related interventions, multiple searches were undertaken in November 2016 on http://www.google.com/, with personalised results disabled. The search terms were naturopath stem cell, acupuncturist stem cell, homeopath stem cell, chiropractor stem cell, midwife stem cell, natural stem cell, alternative stem cell, holistic stem cell and complementary stem cell. For each search term, we attempted to identify 60 clinic websites in order of appearance; however, in some cases (eg, for the search 'complementary stem cell') the Google search results terminated before producing 60 clinic websites. Only web domains for clinics or practitioners with physical addresses were included as results. Supplement shops lacking a clinical component were excluded. 
Table 2 Other treatments offered that reference stem cells (among all web domains, $n=368$ )

\begin{tabular}{|c|c|c|c|}
\hline Treatment type & $\begin{array}{l}\text { Web } \\
\text { domains (n) }\end{array}$ & $\begin{array}{l}\text { Web } \\
\text { domains (\%) }\end{array}$ & Example (excerpt) \\
\hline None & 267 & 72.55 & $N / A$ \\
\hline Prolotherapy & 19 & 5.16 & $\begin{array}{l}\text { 'The leading form of Prolotherapy is Platelet Rich Plasma; also known as } \\
\text { PRP Prolotherapy. Platelets are part of our circulating blood, and they } \\
\text { control blood clotting. Platelets also contain "Platelet Derived Growth } \\
\text { Factors". These growth factors stimulate dormant stem cells to regrow } \\
\text { injured or worn painful joints.' (http://www.drwik.com/) (note: prolotherapy } \\
\text { and platelet-rich plasma are related and were often mentioned together) }\end{array}$ \\
\hline Other & 9 & 2.45 & $\begin{array}{l}\text { 'Patients who undergo oxygen therapy either sit in a hyperbaric room or } \\
\text { a one-person hyperbaric clear, plastic tube, depending upon the illness } \\
\text { that is being treated. In either situation, the air pressured in the chamber is } \\
\text { increased two or three times. The increase in air pressure allows the lungs } \\
\text { to gather more oxygen than normal, subsequently allowing the blood to } \\
\text { carry this extra oxygen throughout the body. The increase in oxygen helps } \\
\text { to fight bacteria and stimulates the release of growth factors and stem } \\
\text { cells, substances that help to promote healing.' (http://www.painendshere. } \\
\text { com/) }\end{array}$ \\
\hline
\end{tabular}

$\mathrm{N} / \mathrm{A}$, not available.

Once all the websites were collected, duplicates were identified and removed. Websites were shortened to their basic domain name (eg, http://www.stemcellclinic.com/ about_us would be shortened to http://www.stemcellclinic.com/), and combined into a unified data set of 403 unique web domains. We chose in our methodology to sort the clinic web domains by coding categories, such as practitioner type, rather than by the search terms under which they appeared. This prevented miscategorisation in instances where a practitioner type appeared that was different from the search term. For example, naturopath clinic websites were found in the 'acupuncturist stem cell' search. Therefore, information connecting a web domain to the search term in which it occurred was discarded.

A coding frame-that is, a framework for analysing specific language content on the websites and converting it to numerical data for analysis-was developed using both inductive and deductive methodologies, and content analysis was then performed. ${ }^{25}$ The coding frame is summarised in box 1. Coding of the websites was undertaken between February 2017 and May 2017. Initially, each web domain was manually searched to determine the country in which the clinic was located, as well as the type(s) of practitioners advertised (eg, naturopath, midwife, medical doctor). Subsequently, domain-specific Google searches were undertaken in the form of 'stem cell site:URL', to identify all mentions of stem cells in each domain. Coders then applied the coding frame to the domain by analysing all webpages linked from the Google search results. Excerpts were copied to note examples of the statements and claims present.

During coding, it became clear that several of the domains had become non-functional, had redirected to a different unrelated domain, no longer contained any mention of stem cells or on closer analysis were not clinic websites (eg, blogs, online stores). These domains were excluded, leaving a final sample of 368 web domains to analyse.

\section{RESULTS}

Of the 368 web domains, 243 marketed stem cell therapies, and 116 marketed other interventions where stem cells were mentioned in the description of the treatment or its effects (eg, stem cells were 'activated' or 'stimulated'), including platelet-rich plasma injections (88), prolotherapy (19) and others (9). Many websites advertised stem cell transplantation from multiple sources, such as adipose-derived (112), bone marrow-derived (100), blood-derived (28), umbilical cord-derived (26) and others. Plant stem cell-based treatments and products (eg, skin creams) (20) were also advertised. Tables 1 and 2 summarise the types of therapies offered and provide excerpts from selected websites as examples.

Treatment targets for stem cell treatments varied, but were most commonly pain/injury relating to the bones, joints and muscles (182), illness (diseases or maladies including autoimmune disorders, degenerative conditions, genetic disorders, infectious diseases and environmental harms, other than chronic conditions primarily affecting the bones, joints and muscles) (82), cosmetic concerns (52), non-cosmetic ageing (44) and sexual enhancement (18). Table 3 summarises treatment targets and provides excerpts showing examples of claims noted.

The majority of the clinics from the sample were located in the USA (see table 4). Also, despite using CAM-focused search terms and not searching specifically for medical 
doctors, over half of the web domains marketing stem cell therapies featured medical doctors (130). Also, 66 of the 368 websites featured medical doctors along with at least one CAM practitioner. Other common practitioner types included chiropractors (53), naturopaths (44) and acupuncturists (20). Table 5 summarises the practitioner types noted in the results.

A low percentage of the domains advertising stem cell therapies stated that there was limited evidence of efficacy of the interventions $(18.93 \%)$ or that there was evidence of inefficacy $(12.76 \%)$. Only some domains mentioned general risks associated with an intervention (such as the small risk of infection or allergic reaction from injecting a substance with a needle) (24.69\%), and even fewer mentioned risks specific to the mode of therapy (such as the potential to cause further damage to a joint by injecting cells into it) (5.76\%). A minority of domains mentioned the regulatory (eg, FDA) status of the intervention $(30.86 \%$ ), and only $33.33 \%$ noted that the therapy is experimental or unproven. Hype language, defined as exaggerated or extreme language when speaking about potential benefits (eg, breakthrough, revolutionary, cure, incredible, amazing, magical) was found on $31.69 \%$ of the web domains offering stem cell therapies. See table 6 for greater detail on the disclosures made on the web domains and for examples of excerpts.

Intercoder reliability testing was completed for 79 of the 368 entries, or $21.47 \%$ of the sample. Kappa scores

Table 3 Advertised stem cell treatment targets (among web domains marketing stem cell therapies, $n=243$ )

\begin{tabular}{|c|c|c|}
\hline $\begin{array}{l}\text { Treatment target } \\
\text { type }\end{array}$ & $\begin{array}{l}\text { Web } \\
\text { domains (n) }\end{array}$ & $\begin{array}{l}\text { Web } \\
\text { domains (\%) Example (excerpt) }\end{array}$ \\
\hline
\end{tabular}

\begin{tabular}{llll}
\hline Unspecified & 6 & 2.47 & N/A \\
$\begin{array}{l}\text { Pain/injury } \\
\text { (musculoskeletal) }\end{array}$ & 182 & 74.90 & $\begin{array}{l}\text { 'These treatments enhance the natural cycles of repair in chronically } \\
\text { injured joints, ligaments and tendons. Regenerative injections are an } \\
\text { effective treatment for all manner of acute and chronic back and neck } \\
\text { pain, as well as osteoarthritis and injuries to the hip, knee, shoulder, } \\
\text { elbow, wrist, foot and ankle.' (http://www.myctm.org/) }\end{array}$
\end{tabular}

\begin{tabular}{|c|c|c|c|}
\hline Other illness/disease & 82 & 33.74 & $\begin{array}{l}\text { 1. 'The Lung Institute offers stem cell treatment for many major pulmonary } \\
\text { conditions, including chronic obstructive pulmonary disease (COPD), } \\
\text { emphysema, chronic bronchitis, pulmonary fibrosis and interstitial lung } \\
\text { disease.' (http://www.lunginstitute.com/) } \\
\text { 2. 'In Dr. Steenblock's experience the use of the patient's own bone } \\
\text { marrow is the safest, simplest, and cheapest method to treat CHF } \\
\text { [congestive heart failure] with stem cells and in his opinion gets } \\
\text { consistently good or better results than those more expensive and risky } \\
\text { methods of treatment described above.' (personalized-regenerative- } \\
\text { http://www.medicine.com/) } \\
\text { 'Stem Cells - This treatment has great therapeutic potential given to } \\
\text { the cells ability in regulating the immune system, regenerating tissues } \\
\text { and organs and preventing pathologies.' (http://www.flordelasalud. } \\
\text { com/) } \\
\text { 'Stem Cell Vaccine Therapy can be used with other surgical } \\
\text { interventions to replace post surgical chemotherapy, or can } \\
\text { be used as a stand alone treatment if indicated.' (http://www. } \\
\text { stemcelltreatmentinstitute.com/) }\end{array}$ \\
\hline Ageing & 44 & 18.11 & $\begin{array}{l}\text { 'Thai Regen offers stem cell therapy and other medical and holistic healing } \\
\text { treatments in Thailand (Bangkok and Chiang Mai) for the prevention and } \\
\text { treatment of degenerative disease as well as for anti-aging and body } \\
\text { rejuvenation.' (http://www.thairegen.com/) }\end{array}$ \\
\hline Sexual enhancement & 18 & 7.41 & $\begin{array}{l}\text { 'There are exciting new treatment options for men suffering from } \\
\text { erectile dysfunction that can provide natural and lasting results without } \\
\text { medication, including stem cell therapy.' } \\
\text { (https://www.innovativecosmeticsurgery.com/) }\end{array}$ \\
\hline
\end{tabular}


Table 4 Clinic country of origin (as noted on web domain)

\begin{tabular}{|c|c|c|c|c|}
\hline \multirow[b]{2}{*}{ Country } & \multicolumn{2}{|c|}{$\begin{array}{l}\text { Full sample } \\
(n=368)\end{array}$} & \multicolumn{2}{|c|}{$\begin{array}{l}\text { Only clinics } \\
\text { offering stem cell } \\
\text { therapies }(n=243)\end{array}$} \\
\hline & Total & $\%$ & Total & $\%$ \\
\hline USA & 295 & 80.16 & 208 & 85.60 \\
\hline India & 19 & 5.16 & 8 & 3.29 \\
\hline Canada & 14 & 3.80 & 7 & 2.88 \\
\hline Australia & 8 & 2.17 & 2 & 0.82 \\
\hline Mexico & 7 & 1.90 & 6 & 2.47 \\
\hline UK & 7 & 1.90 & 1 & 0.41 \\
\hline Thailand & 6 & 1.63 & 4 & 1.65 \\
\hline China & 3 & 0.82 & 2 & 0.82 \\
\hline Isreal & 2 & 0.54 & 0 & 0.00 \\
\hline Denmark & 2 & 0.54 & 2 & 0.82 \\
\hline $\begin{array}{l}\text { United Arab } \\
\text { Erimates }\end{array}$ & 1 & 0.27 & 1 & 0.41 \\
\hline Netherlands & 1 & 0.27 & 1 & 0.41 \\
\hline Serbia & 1 & 0.27 & 1 & 0.41 \\
\hline Lithuania & 1 & 0.27 & 0 & 0.00 \\
\hline Ireland & 1 & 0.27 & 0 & 0.00 \\
\hline Pakistan & 1 & 0.27 & 1 & 0.41 \\
\hline Hong Kong & 1 & 0.27 & 1 & 0.41 \\
\hline New Zealand & 1 & 0.27 & 1 & 0.41 \\
\hline
\end{tabular}

were calculated based on intercoder agreement and are summarised in table 7 . The scores reflect substantial to perfect agreement between coders. ${ }^{26}$

Selected examples of stem cell-related claims, sorted by practitioner type listed on the relevant web domain, are included in table 8 .

Table 5 Practitioner types noted on web domains

\begin{tabular}{|c|c|c|c|c|}
\hline \multirow[b]{2}{*}{ Practitioner } & \multicolumn{2}{|c|}{$\begin{array}{l}\text { Full sample } \\
(n=368)\end{array}$} & \multicolumn{2}{|c|}{$\begin{array}{l}\text { Only clinics } \\
\text { offering stem cell } \\
\text { therapies }(n=243)\end{array}$} \\
\hline & Total & $\%$ & Total & $\%$ \\
\hline Medical doctor & 161 & 43.75 & 130 & 53.50 \\
\hline Naturopath & 63 & 17.12 & 44 & 18.11 \\
\hline Chiropractor & 61 & 16.58 & 53 & 21.81 \\
\hline Acupuncturist & 36 & 9.78 & 20 & 8.23 \\
\hline Midwife & 33 & 8.97 & 0 & 0.00 \\
\hline Homeopath & 27 & 7.34 & 8 & 3.29 \\
\hline Massage therapist & 13 & 3.53 & 13 & 5.35 \\
\hline Aesthetician & 9 & 2.45 & 7 & 2.88 \\
\hline Registered nurse & 7 & 1.90 & 6 & 2.47 \\
\hline Ayurvedic doctor & 2 & 0.54 & 1 & 0.41 \\
\hline Other & 74 & 20.11 & 57 & 23.46 \\
\hline Not specified & 34 & 9.24 & 22 & 9.05 \\
\hline
\end{tabular}

\section{DISCUSSION}

This research was undertaken to determine the extent to which CAM practitioners are involved in online advertising of stem cell-related interventions, what kinds of claims are made and what relevant scientific, ethical and legal disclosures accompany these representations. The results show that CAM practitioners are now highly involved in advertising these interventions, often advertise medically serious procedures such as autologous bone marrow stem cell transplantation and largely fail to make reasonable and essential disclosures.

Indeed, it is concerning that the majority of the web domains advertising stem cell-related interventions did not include disclosures about scientific evidence of efficacy (or lack thereof), about general and/or specific risks associated with the intervention(s) offered, about the experimental nature of the treatments or about their regulatory status. This finding is consistent with past research on the marketing of stem cell therapies, which has indicated similar deficiencies and potentially problematic advertising practices. ${ }^{12} 132728$ Failing to provide accurate and complete information may impact potential patients' ability to give informed consent to treatment, and exaggerated claims, including potentially false, misleading or deceptive promotion, may risk running afoul of marketing regulations.

Adipose-derived autologous stem cell transplantation was the most common type of therapy advertised (table 1). This may reflect the fact that the procedure to remove fat tissue is generally less intensive and invasive than extracting bone marrow, though the latter was also popular. Together, these two forms of therapy comprised the dominant offerings observed. Yet, there can be safety issues with these therapies as noted by bodies like the International Society of Stem Cell Research, and many are not approved by national regulatory institutions. ${ }^{45}$

The health targets of stem cell therapies largely consisted of chronic conditions like musculoskeletal pain and deterioration, and this extended to the 'other illness/disease' category, where conditions like chronic obstructed pulmonary disorder and congestive heart failure were targeted. This distribution reflects a common demographic of individuals who may have unmet medical needs (eg, pain not satisfactorily remedied by conventional treatment), for whom conventional medicine can provide neither an effective solution nor satisfactory relief from daily symptoms. ${ }^{29}$ A strong secondary focus on arguably less medically serious conditions related to ageing, cosmetics and sexuality also reflects the creep of these multibillion dollar industries into the realm of stem cells. ${ }^{30}$

It is notable to see how many CAM practitioners are offering stem cell-related interventions or are in some other way using stem cells to market their products or services. Of course, it is important to distinguish interventions involving stem cell injections and those that merely reference stem cells for advertising effect (or in some cases, potentially for scientifically justified reasons). The former can present serious physical risks to patients receiving injections, and 
Table 6 Claims and language used (among web domains marketing stem cell therapies, $\mathrm{n}=243$ )

\begin{tabular}{|c|c|c|c|c|c|}
\hline Claim/language used & Yes & No & $\%$ (yes) & $\%$ (no) & Example (excerpt) fulfilling 'yes' coding selection \\
\hline $\begin{array}{l}\text { States evidence of } \\
\text { inefficacy }\end{array}$ & 31 & 212 & 12.76 & 87.24 & $\begin{array}{l}\text { 'Those who undergo stem cell treatment normally have about a } \\
15 \% \text { likelihood of receiving no benefits from stem cell treatment.' } \\
\text { (http://www.regenorthoclinic.com/) }\end{array}$ \\
\hline $\begin{array}{l}\text { States that there is } \\
\text { limited evidence of } \\
\text { efficacy }\end{array}$ & 46 & 197 & 18.93 & 81.07 & $\begin{array}{l}\text { 'Stem cells have the potential to cure the disease from its root; } \\
\text { however it is not approved by FDA as proven results are not yet } \\
\text { available.' (http://www.stemgenn.com/) }\end{array}$ \\
\hline
\end{tabular}

efficacy

\begin{tabular}{|c|c|c|c|c|}
\hline States general risks & 60 & 183 & 24.69 & 75.31 \\
\hline $\begin{array}{l}\text { States risks specific to } \\
\text { mode of therapy }\end{array}$ & 14 & 229 & 5.76 & 94.24 \\
\hline
\end{tabular}

'Any time you penetrate the skin there is a small risk of infection. Our procedures are performed using strict aseptic techniques, so infection is rare, occurring in only about 1 of every 10,000 patients. Other possible complications include allergic reactions to local anesthetic and bleeding, and both are extremely rare.' (http://www.dhpmcharlotte.com/)

States risks speci
mode of therapy

'There are certain unavoidable risks and potential side effects and complications to the Treatments, including without limitation swelling; increased pain; bleeding; dizziness, numbness; scarring; scar or keloid formation; asymmetry; allergic reaction; discoloration; soreness, itching, a feeling of "lumpiness" or permanent skin contour irregularities at the site of Treatments; all of which may be permanent. Treatment may very rarely cause infection; injury to nerves, temporary or permanent alteration in sensation; the need for additional surgery or hospitalization; spinal cord injuries, pneumothorax (temporary lung collapse), paralysis, or other serious or debilitating injuries or death.' (http://www. mauiregenerativemedicine.com/)

\begin{tabular}{|c|c|c|c|c|c|}
\hline States regulatory status & 75 & 168 & 30.86 & 69.14 & $\begin{array}{l}\text { 'The Food and Drug Administration (FDA) has NOT approved the } \\
\text { use of adult stem cells/SVF for any disorder. The Cell Surgical } \\
\text { Network and its affiliate treatment centers are not offering stem } \\
\text { cell therapy as a cure for any condition, disease, or injury. No } \\
\text { statements or implied treatments on this website have been } \\
\text { evaluated or approved by the FDA. This website contains no } \\
\text { medical advice.' (http://www.innovationsstemcellcenter.com/) }\end{array}$ \\
\hline $\begin{array}{l}\text { States therapy is } \\
\text { experimental or unproven }\end{array}$ & 81 & 162 & 33.33 & 66.67 & $\begin{array}{l}\text { 'That being said, the cutting edge stem cell therapy is still } \\
\text { considered experimental. Stem cells are currently being studied } \\
\text { in many arenas, and the prospect for health improvement using } \\
\text { stem cells is great, but many results at this point have only been } \\
\text { studying on very few patients. We perform stem cell therapy for } \\
\text { the benefit of our patients, and are not involved in any clinical } \\
\text { trials.' } \\
\text { (http://www.drandrewlipton.com/) }\end{array}$ \\
\hline
\end{tabular}

while the latter can also cause harm, they tend to be less invasive and lower risk. Stem cell science, research and clinical application are very specialised, and it is highly unlikely that the broad array of CAM practitioners noted in this study each have the requisite expertise to work with stem cells in a safe and effective manner. ${ }^{6}$ In some cases, 
Table 7 Cohen's kappa scores for intercoder reliability (79/368 recoded $=21.5 \%)$

\begin{tabular}{ll}
\hline Practitioner & 0.8665 \\
\hline Modes of stem cell therapy offered & 0.9672 \\
\hline Advertised stem cell treatment targets & 0.9009 \\
\hline Other treatments offered that reference stem cells & 0.9268 \\
\hline States evidence of inefficacy & 1.0000 \\
\hline States that there is limited evidence of efficacy & 1.0000 \\
\hline States general risks & 1.0000 \\
States risks specific to mode of therapy & 1.0000 \\
States regulatory status & 0.9617 \\
States therapy is experimental or unproven & 0.9660 \\
\hline Uses hype language & 1.0000 \\
\hline
\end{tabular}

and depending on the jurisdiction, these practitioners are either unregulated, regulated less stringently than medical doctors or have been granted self-regulation but have failed to either establish and/or enforce any clearly defined evidence-based standard of care. ${ }^{31}$ Professional regulation-including self-regulation-of CAM providers is growing, ${ }^{32} 33$ though there remains concern about a lack of appropriate oversight. ${ }^{12}$ Where a particular category of CAM practitioners is professionally regulated, employing professional oversight and discipline may be one option for controlling problematic practices. However, the ability and willingness of CAM regulators to set and enforce relevant standards in this context remains to be seen. At present it seems likely that other strategies-such as the use of consumer protection and truth-in-advertising laws-may be more readily available and broadly relevant.

Despite our focus on CAM in the methodology and the presence of many CAM practitioners marketing stem cell therapies in our results, we were surprised that medical doctors were still the most common practitioner type noted. These results highlight again the critical role the medical community and its regulatory bodies, such as medical colleges, have in ensuring physicians are not engaging in unprofessional conduct with respect to their clinical or marketing practices. ${ }^{816} 34-36$

In this research, we found that 116 web domains advertised non-stem cell interventions with language that references stem cells (see table 2 for examples), which was arguably done in order to leverage the excitement surrounding stem cell science in order to market products. The application of truth-in-advertising laws may be one way to ensure that claims made are not false or misleading in a material respect, ${ }^{37}$ and thus do not contribute to this kind of inappropriate 'scienceploitation'.

Many countries around the world have laws and policies, supported by enforcement agencies, prohibiting demonstrably false or misleading marketing claims. ${ }^{18}$ For example, in the USA, the Federal Trade Commission regulates marketing claims using the Federal Trade Commission Act and prohibits 'deceptive and unfair acts or practices', that is to say, those that mislead consumers and affect their 'behavior or decisions about the product or service'.${ }^{38}{ }^{39}$ Similarly, in Canada, the Competition Bureau enforces the Competition Act which requires that representations must not be false or misleading 'in a material respect', that is to say, in a manner that could 'influence the ordinary consumer to buy or use the advertised product or service'. ${ }^{40}$ Although not without their challenges in terms of application and enforcement, these consumer protection and truth-in-advertising governance frameworks are certainly relevant to, and in some cases should be triggered by, the questionable claims found in this study, especially those regarding the safety, efficacy and the supposedly 'revolutionary' quality of some interventions advertised.

\section{Limitations}

While the study covered the majority of the most common types of CAM providers used in the USA (excepting massage therapists which were not specifically searched for given the context of stem cells, but were nonetheless noted) ${ }^{42}$ the search terms selected did not fully encompass the gamut of existing CAM practitioner types, omitting many less common types, including reiki providers and reflexologists. Moreover, given the fact that the search was undertaken in the English language on the American version of the Google search engine, there may have been an overrepresentation of American and/or Englishspeaking clinics. As mentioned in the methods, the coding frame was applied only to the specific webpages on web domains where the term 'stem cell' was found by Google, and not to the entirety of existing content on a given domain. It is possible that broad disclaimers and other relevant information were therefore excluded. Finally, our research focus was on exploring how, and by whom, stem cells are used to market health services and interventions. Though we did not evaluate claims against peer-reviewed scientific literature and thus cannot make any definitive statements as to the accuracy of any of the marketing claims, in future research this important task could be undertaken.

\section{CONCLUSION}

Our research indicates that clinics using stem cell language to advertise their services do so in many different forms, for many different conditions, and often without disclosing evidence, risks or regulatory information. Many CAM practitioners are now actively involved in offering and advertising stem cell-based interventions, often alongside physicians. Professional regulation may provide one avenue of oversight and enforcement for problematic conduct, but its application will be limited to regulated health professionals and impacted considerably by the strength (and will) of the regulatory regime. The questionable nature of many of the claims we found, along with the absence of important qualifying information, suggests consumer protection and truth-in-advertising regulations are highly relevant to this market and indeed could prove very useful in constraining 
Table 8 Selected examples of stem cell-related claims made, by practitioner type listed on website

\section{Practitioner type Examples of claims}

Medical doctor 'When it comes to Regenerative Orthopedics, stem cells are a game changer. They make our regenerative injection techniques much more effective. Stem cell therapy is the strongest, fastest and most effective regenerative stimulus we have.' (http://www.regenortho.com/)

Naturopath 'Our regenerative and biological treatments include Prolotherapy, Platelet Rich Plasma PRP, and Adult Stem Cell Therapies. These treatments enhance the natural cycles of repair in chronically injured joints, ligaments and tendons. Regenerative injections are an effective treatment for all manner of acute and chronic back and neck pain, as well as osteoarthritis and injuries to the hip, knee, shoulder, elbow, wrist, foot and ankle. For our patients who have been told that their only solution is surgery or a life on pain medications, the vast majority have been able to achieve drug-free, pain-free function without surgery joint replacement.' (http://www.myctm.org/)

Acupuncturist 'This QiGong form has proven scientific effects of stimulating and activating adult stem cells in our bone marrow; gently elongating and improving flexibility of the spine, alleviating neck, back and joint pain.' (http://www.taoistacupunture.com/)

Chiropractor 'Stem cell therapy: If you are suffering with chronic pain, this new breakthrough treatment could change your life! Eliminate knee pain with the industry's latest proven alternative to surgery and steroids.' (http:// www.activephysicalmedicine.com/)

Homeopath 'Every day, Marnie supports women in restoring health and well-being to their digestive systems using homeopathy and Plant Stem Cells so they have the energy to do the things they love.' (http://www. resplendenthealing.com/)

Midwife 'Cord blood contains magical stem cells, and the idea is that if your baby becomes ill in the future you may be able to use these cells as treatment.' (http://www.katybirthcenter.com/)

Ayurvedic doctor 'Experts say, "Successful regenerative medicine centered on human cells could potentially replace a number of major molecular pharmaceuticals and medical prostheses." Heart Cardiac myocytes possess the capacity for regeneration after heart attacks. Heart tissue can also be regenerated from stem cells derived from bone marrow.'(http://www.ayurvedicscience.com/)

Aesthetician 'ARGAN PLANT STEM CELLS: These are the first plant stem cells with proven effectiveness for deepseated cell protection and rejuvenation. Clinical results confirm Argan Stem Cells reduce wrinkles by $26 \%$ while tightening, toning and improving skin density.' (http://www.jadeholisticspa.com/)

Registered nurse 'Stem cells can be found in every tissue in every human body, but are especially concentrated in bone marrow, blood, and adipose(fatty) cells. Stems cells are what make regenerative therapies like PRP therapy so effective; by harvesting cells from fatty tissue in this new treatment, we can send 10000x more stem cells into your body than PRP therapy!' (http://www.drandrewlipton.com/) (registered nurses were only featured alongside other practitioners; Andrew Lipton is an osteopath)

Massage therapist 'From Aloe Vera to L-Ascorbic Acid to Peptides and Plant Stem Cells, every ingredient in my formulas works in harmony with the skin's natural processes.' (http://www.bodhiholisticspa.com/)

Other

1. (Pharmacist) 'Stem Cell Worx Intraoral Spray is the world's only natural stem cell supplement in an intramural spray, and it's available at The Compounding Pharmacy of Beverly Hills today. It is designed specifically to activate your own adult stem cells naturally and provides robust immunity.' (http://www. compoundingexpert.com/)

2. 'The marrow is rich in Mesenchymal Stem Cells, which are responsible for healing damaged tissues. The stems cells are isolated from the marrow sample and platelets are isolated from the blood sample. After preparation, these two components will be reinjected directly into the damaged area of the joint using advanced imaging guidance. This ensures the cells are delivered to the exact location of need.' (http://www.louisvillebodyworks.com/)

some of the more egregious marketing practices identified. The applicability of these regulatory regimes do not depend on the professional status of those advertising the services and rather typically focus on the general impression the representation conveys to the public. ${ }^{43}$

The use of consumer protection and truth-in-advertising regulation to curtail misleading advertising in the private, direct-to-consumer market for stem cell interventions is an area well worth further research and consideration. Important questions will include how existing legal and policy tools could be used to regulate the claims made by clinics advertising stem cell-related interventions and how to effectively enforce the law among clinics or individual practitioners that engage in misleading marketing practices, particularly given the cross-border nature of this market. A related issue that also bears monitoring is how the practices of clinics offering unproven stem cell interventions relate to concerns about 'scienceploitation' and its potential harms. Many clinics seem to be engaging in scienceploitation, which can seriously obfuscate public 
discourse, mislead the public and make it difficult to discern real science from marketing claims that merely reference scientific sounding terminology. The marketing of unproven stem cell therapies has the potential to harm patients and to harm the reputation of stem cell science. It is incumbent on regulators and policymakers to take a proactive approach to managing the risks associated with the growing private market for stem cell-related interventions, and addressing misleading marketing practices is an important part of this strategy.

Acknowledgements The authors thank Robyn Hyde-Lay for her advice and guidance, and for her aid in developing applications to secure funding for this project. The authors would also like to thank research assistants Daniel Downie, Yassine El Balhouli and Corinna Liu for their help with data collection.

Contributors All authors designed the study, analysed the data and wrote the article.

Funding This work was supported by the Stem Cell Network, grant number FY17/ PP1 RES0032389, and the Trudeau Foundation, grant number RES0019335.

Competing interests None declared.

Patient consent Not applicable.

Provenance and peer review Not commissioned; externally peer reviewed.

Data sharing statement Original data set and time-stamped screenshots of all example statements found in the tables are available upon request to the corresponding author.

Open Access This is an Open Access article distributed in accordance with the Creative Commons Attribution Non Commercial (CC BY-NC 4.0) license, which permits others to distribute, remix, adapt, build upon this work non-commercially, and license their derivative works on different terms, provided the original work is properly cited and the use is non-commercial. See: http://creativecommons.org/ licenses/by-nc/4.0/

(C) Article author(s) (or their employer(s) unless otherwise stated in the text of the article) 2018. All rights reserved. No commercial use is permitted unless otherwise expressly granted.

\section{REFERENCES}

1. International Society for Stem Cell Research. ISSCR 2017 Highlights New Discoveries in Stem Cell Research \& Progress Toward Clinical Therapies.25 April 2017 http://www.isscr.org/home/about-us/ news-press-releases/2016/2017/04/25/isscr-2017-highlights-newdiscoveries-in-stem-cell-research-progress-toward-clinical-therapies (accessed $14 \mathrm{Jul}$ 2017)

2. Guzzo RM, O'Sullivan MB. Human pluripotent stem cells: advances in chondrogenic differentiation and articular cartilage regeneration. Curr Mol Biol Rep 2016;2:113-22.

3. Caulfield T, Sipp D, Murry CE, et al. Confronting stem cell hype. Science 2016;352:776-7.

4. International Society for Stem Cell Research. Patient handbook on

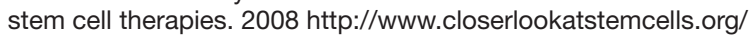
docs/default-source/patient-resources/patient-handbook-english. pdf?sfvrsn=4 (accessed 14 Jul 2017).

5. A Closer Look at Stem Cells. Nine things to know about stem cell

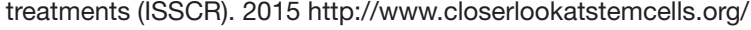
stem-cells-and-medicine/nine-things-to-know-about-stem-celltreatments (accessed 14 Jul 2017).

6. Daley GQ. Polar Extremes in the Clinical Use of Stem Cells. N Engl J Med 2017;376:1075-7.

7. Deans RJ, Gunter KC, Dominici M, et al. Part 5: Unproven cell therapies and the commercialization of cell-based products. Cytotherapy 2016;18:138-42.

8. Ikonomou L, Freishtat RJ, Wagner DE, et al. The global emergence of unregulated stem cell treatments for respiratory diseases. Professional societies need to act. Ann Am Thorac Soc 2016;13:1205-7.

9. Berger I, Ahmad A, Bansal A, et al. Global distribution of businesses marketing stem cell-based interventions. Cell Stem Cell 2016;19:158-62.
10. U.S. Food \& Drug Administration. Vaccines, blood \& biologics; cellular \& gene therapy products; approved products; marketed products. January 172017 https://www.fda.gov/BiologicsBloodVa ccines/CellularGeneTherapyProducts/ApprovedProducts/default.htm (accessed 14 Jul 2017).

11. Ogbogu U, Rachul C, Caulfield T. Reassessing direct-to-consumer portrayals of unproven stem cell therapies: is it getting better? Regen Med 2013;8:361-9.

12. Regenberg AC, Hutchinson LA, Schanker B, et al. Medicine on the fringe: stem cell-based interventions in advance of evidence. Stem Cells 2009;27:2312-9.

13. Turner L, Knoepfler P. Selling stem cells in the USA: assessing the direct-to-consumer industry. Cell Stem Cell 2016;19:154-7.

14. The Cystic Fibrosis Foundation. Stem cell therapies and research for cystic fibrosis. March 92015 https://www.cff.org/News/NewsArchive/2015/Stem-Cell-Therapies-and-Research-for-CysticFibrosis/ (accessed 22 Aug 2017).

15. Rosemann A, Sleeboom-Faulkner M. New regulation for clinical stem cell research in China: expected impact and challenges for implementation. Regen Med 2016;11:5-9.

16. Sipp D, Caulfield T, Kaye J, et al. Marketing of unproven stem cellbased interventions: a call to action. Sci Transl Med 2017;9:eaag0426.

17. Health on the Net Foundation. The commitment to reliable health and medical information on the internet.. http://www.hon.ch/HONcode/ Patients/Visitor/visitor.html (accessed 16 Nov 2017).

18. Chang DT, Abouassaly R, Lawrentschuk N. Quality of health information on the internet for urolithiasis on the Google search engine. Adv Urol 2016;2016:1-5.

19. Ogbogu $U$. Combating unlicensed stem cell interventions through truthful advertising law: a survey of regulatory trends. MJLH 2016;9:311-35

20. Zarzeczny A, Caulfield T, Ogbogu U, et al. Professional regulation: a potentially valuable tool in responding to "stem cell tourism". Stem Cell Reports 2014;3:379-84.

21. California Naturopathic Doctors Association. Naturopathic doctors are primary care doctors. CNDA. http://www.calnd.org/files/CNDA\% 20NDs\%20are\%20Primary\%20Care\%20Doctors\%20FINAL\%20218-13.pdf (accessed 15 Nov 2017).

22. The American Association of Naturopathic Physicians. What is a Naturopathic Doctor? AANP. 2017 http://www.naturopathic.org/ content.asp?contentid=60 (accessed 15 Nov 2017).

23. Caulfield T, Rachul C. Supported by science?: what Canadian naturopaths advertise to the public. Allergy Asthma Clin Immunol 2011;7:14.

24. Caulfield T. Blinded by science: modern-day hucksters are cashing in on vulnerable patients. The walrus, sept. 2011;12 https://thewalrus. ca/blinded-by-science/

25. Elo $\mathrm{S}$, Kyngäs $\mathrm{H}$. The qualitative content analysis process. J Adv Nurs 2008;62:107-15

26. McHugh ML. Interrater reliability: the kappa statistic. Biochem Med 2012;22:276-82.

27. Lau D, Ogbogu U, Taylor B, et al. Stem cell clinics online: the direct-to-consumer portrayal of stem cell medicine. Cell Stem Cell 2008;3:591-4.

28. Fujita M, Hatta T, Ozeki R, et al. The current status of clinics providing private practice cell therapy in Japan. Regen Med 2016;11:23-32.

29. Artus M, Croft P, Lewis M. The use of CAM and conventional treatments among primary care consulters with chronic musculoskeletal pain. BMC Fam Pract 2007;8:26.

30. Business Wire. Research and Markets: Global Cosmetics Market 2015-2020: Market was \$460 Billion in 2014 and is Estimated to Reach $\$ 675$ Billion by 2020. July 27 2015. https://www.businesswire. com/news/home/20150727005524/en/Research-Markets-GlobalCosmetics-Market-2015-2020-Market

31. Weeks C. Are we being served by the regulation of naturopaths? Not if patients are still being misled. The globe and mail. 2016. https:// www.theglobeandmail.com/life/health-and-fitness/health/canadiannaturopaths-need-to-follow-the-rules-if-they-want-regulation/ article29785140/ (accessed 14 Jul 2017).

32. Gilmour J, Kelner M, Wellman B. Opening the door to complementary and alternative medicine: self-regulation in Ontario. Law and Policy 2002;24:149-74.

33. Welsh S, Kelner M, Wellman B, et al. Moving forward? Complementary and alternative practitioners seeking self-regulation. Sociol Health IIIn 2004;26:216-41.

34. Medical Board of California (MBC). In the Matter of the Accusation against Darryl Matthew See, M.D. Division of Medical Quality, Medical Board of California, Department of Consumer Affairs, State of California. Case No. 04-2004-161179.. 2007. http://www. casewatch.org/board/med/see/surrender.pdf 
35. SMC (Singapore Medical Council). Disciplinary inquiry for Dr Wong Yoke Meng. 2010. http://www.healthprofessionals.gov.sg/content/ dam/hprof/smc/docs/press_releases/14.Press\%20Release_Dr\% 20Wong\%20Yoke\%20Meng_3Nov10.pdf

36. SMC (Singapore Medical Council). Press release: disciplinary inquiry for Dr Wong Yoke Meng. 2010. http://www.

healthprofessionals.gov.sg/content/dam/hprof/smc/docs/press releases/15.Press\%20Release_Dr\%20Wong\%20Yoke\%20Meng4_ 9Nov10.pdf

37. Competition Act, R.S.C. 1985, c. C-34, s. 74.01(1)(a).

38. Federal Trade Commission. (2000) Advertising and Marketing on the Internet: Rules of the Road. https://www.ftc.gov/tips-advice/ business-center/guidance/advertising-marketing-internet-rules-road (accessed 14 Jul 2017).
39. Federal Trade Commission.. (2016) Federal Trade Commission Act Sect 5: Unfair or Deceptive Acts or Practices.. (https://www. federalreserve.gov/boarddocs/supmanual/cch/ftca.pdf.

40. Competition Act, RSC 1985, c C-34.

41. Competition Bureau. "False and misleading representations and deceptive marketing practices under the competition act". 3 Nov 2011. http://www.competitionbureau.gc.ca/eic/site/cb-bc.nsf/eng/ 03133.htm

42. Barnes PM, Bloom B, Nahin R. CDC National Health Statistics Report \#12. Complementary and alternative medicine use among adults and children. United States, 2008. Dec 102008.

43. Competition Bureau. False or misleading representations and deceptive marketing practices. http://www.competitionbureau.gc.ca/ eic/site/cb-bc.nsf/eng/03133.html 